ПРОБЛЕМЫ РАЗВИТИЯ ГОСУДАРСТВА И ПРАВА В УСЛОВИЯХ ЦИФРОВИЗАЦИИ

\author{
CHALLENGES TO THE DEVELOPMENT \\ OF STATE AND LAW IN A DIGITAL ENVIRONMENT
}

УДК $341 ’ 4$

DOI 10.33184/pravgos-2020.4.2

\title{
INFORMATION TECHNOLOGIES - THE CHALLENGE OF THE TIME
}

\author{
KHAZIEVA Rushana Raufovna \\ Ph.D., Associate Professor of the Chair of International Law and International \\ Relations of the Bashkir State University, Ufa, Russia. \\ E-mail: rushanakhazieva@mail.ru

\section{YUSUPOVA Rozaliya Rimovna} \\ Ph.D., Associate Professor of the Chair of International law \\ and International Relations of the Bashkir State University, Ufa, Russia. \\ E-mail: rozaliya-yusupova@yandex.ru
}

This article focuses on information technologies and gives their classification. The advantages and disadvantages of the introduction of the latest information, telecommunication and cybernetic technologies are highlighted. The authors draw attention to the necessity to unite efforts of all countries regarding information security. It is emphasized that in modern conditions the information systems of one country are part of the global system, which in turn leads to the vulnerability of information systems and the possibility of external influence on politics and the economy. Purpose of the article: to show the positive and negative consequences of the achievements of information exchange. Methods: general scientific methods of theoretical knowledge, as well as general logical methods and research techniques are used. Results: In modern conditions of globalization and integration of various world systems, information security issues should remain a priority and be considered in close cooperation of all countries.

Keywords: information revolution; information technologies; information security; state policy; information flow. 
The successful development of modern information systems undoubtedly leads to qualitative changes in our daily life. Russian political scientists note that «in a post-industrial society, information is the decisive resource of a management, while the role of finance is becoming less and less significant» [1, p. 132]. It is well known that there is a direct coherence and cohesion between the information received and the result. Decision-making processes, administration and the quality of it entirely depends on the volume of data received, especially in complex, difficult, conditions of political engagement. Large information flow influences the activity and performance of political structures. The trajectory of information flow from political associations to recipients requires careful processing and proper application. Processing this information flow takes a long time, and there are errors associated with the delay in its intelligibility to the recipient. There is no doubt that information technologies are involved in important social changes, but they do so in different ways, it depends on their interaction with many other factors. Using the political potential of information strategies, the authorities have the opportunity to organize public discourse in a special way, to create stable and at the same time flexible communication between the state and civil structures, all of its permanent counterparties. So, the ability to use the huge potential of information technologies today mostly depends on the effectiveness of state policy. The tasks of combining long-term and short-term political goals that allow connecting the future and the present, the reality and the prospects for the development of politics are in priority today.

The Russian Prime Minister Mikhail Mishustin approved a draft agreement on information interaction between the CIS member states in the field of digital society development. The document implies joint work on common approaches to the development of state policy and legal regulation in the field of digital development of society and the digital economy. «The member countries of the Commonwealth of Independent States (CIS) will work together on common approaches to the development of state policy and legal regulation in the field of digital development of society and the digital economy. The cooperation agreement is to be signed on November 6, 2020 within the framework of the next meeting of the Council of CIS Heads of Governments» ${ }^{1}$.

${ }^{1}$ О подписании Соглашения об информационном взаимодействии государств участников Содружества Независимых Государств в области цифрового развития общества : распоряжение Правительства РФ от 31.10.2020 № 2846-р [Электронный ресурс]. URL: http://static.government.ru/media/files/4Ont2pXmCmq0ltc4kqI0IRGJ3IugCby2.pdf (дата обращения: 22.10.2020). 
The special attention of the countries participating in the agreement will be turned to such areas as the development of information infrastructure and egovernment systems, ensuring the reduction of digital inequality, the creation of comprehensive mechanisms for supporting research activities, training and retraining of personnel.

In January 2016, the 46th session of the World Economic Forum (WEF) was held in Davos (Switzerland). The title topic of the forum was «the fourth industrial revolution» ${ }^{1}$. As the founder and president of the WEF, Klaus Schwab, emphasized in his speech at the opening of the WEF, «humanity is facing a new technological revolution that will radically change our lives, work and attitudes towards each other. Artificial intelligence is already everywhere from self-driving cars and drones to virtual assistants and programs that can translate from foreign languages, invest, develop new drugs and predict cultural interests» ${ }^{2}$, said Schwab.

In the first industrial revolution, the power of water and steam made it possible to mechanize production (i.e. the first and second technological modes). In the second, electricity was used to organize mass production (third way). In the third, electronics and information technology have automated production (the fifth mode). Achievements in the field of cybernetics and informatics are fully and completely integrated into all spheres of human life: physical, digital and biological spheres. The exclusive feature of this phenomenon is its comprehensive and scalable targeting both individual communities and the entire population of the planet. At the same time, it carries unpredictable challenges and risks. The aim of artificial intelligence is to support people in making better, more informed decisions in accordance with their goals [2, p. 147].

In this regard, at the 75th Session of the UN General Assembly, Russian President V.V. Putin urged to find a balance between development and restrictive measures in the IT sphere: «Digital technologies tend to spread uncontrollably and, like conventional weapons, can fall into the hands of all sorts of radicals and extremists not only in regional conflict zones, but also in quite prosperous countries, creating huge risks. We must learn to use new technologies for the benefit of humanity, find the right balance between incentives for the development of artificial intelligence and justified restrictive measures, jointly come to an agreement on regulation that would exclude potential

${ }^{1}$ Какие возможности откроет IV Промышленная Революция - прогноз, представленный на Всемирном экономическом форуме в Давосе [Электронный ресурс]. URL: http://fea.ru/news/6340 (дата обращения 22.10.2020).

${ }^{2}$ Там же. 
threats, and from the point of view of not only military, technological security, but also traditions, law and morality» ${ }^{1}$.

Technologies have become ubiquitous and as a result, the individual has the feeling that he is an important participant in various processes in the globalized world. Using more and more technical means, he becomes a witness of a number of events taking place in different parts of the world [3 p. 146]. But the digital gap reflects and exacerbates existing social, cultural and economic inequalities. For example, in two out of every three countries, more men use the Internet than women. The pandemic has further exposed these and other digital challenges. This was discussed today by the participants of the high-level forum held on the sidelines of the 75th session of the General Assembly with the participation of representatives of such companies as Microsoft, Google and Facebook.

According to the head of the UN, in the context of the COVID-19 pandemic, the necessity to fill in this gap becomes even more urgent. Digital tools have become a lifeline for millions of people. Ultra-powerful computers analyze thousands of drug compounds to identify drug and vaccine candidates. E-commerce platforms market the most essential household items and medical supplies, while video communication platforms enable education and economic activity to continue.

Analyzing the current results of the latest technological revolution, understood as the penetration of information flows into the most secluded corners of life without any exceptions on a global scale, its impact on three components: the world community; the content, i.e. international relations; security.

Basically, the researchers identify mainly the following internationally significant results: firstly, with the advent of new information technologies, the world will no longer be the same. The world order had changed dramatically. Secondly, the blurring of the borders of states will undoubtedly lead to the decentralization of power structures and, as a result, new subjects of the world information space will appear, which will now already operate throughout the entire globe. Thirdly, the importance of information security will increase, since the essence of international conflicts in the international arena and their settlement will change. "We are witnessing the rapid development of information and communication technologies, which have come into all spheres of human life, become interdependent and interconnected with each other at the global level» [4, p. 67]. All of the above allows us to talk about the information revolution.

${ }^{1}$ Владимир Путин выступил с видеообращением на пленарном заседании юбилейной, 75-й сессии Генеральной Ассамблеи Организации Объединенных Наций [Электронный pecypc]. URL: http://www.kremlin.ru/events/president/news/64074 (дата обращения 22.10.2020). 
It should be emphasized that the fourth industrial revolution or the sixth economic order can have a strong impact on domestic and international security. Throughout the history of mankind wars have occurred, they have been a trigger for the improvement of technologies, the introduction of new developments and achievements. For any war is not only human sacrifice, but also the rivalry of countries in technological superiority. In modern reality, the term «hybridity» is used to describe relations between warring states. If in the past military actions took place only on the battlefield and nowadays these are primarily conflicts in the virtual cyber space.

The Russian National Security Strategy in provision 70 determined: «To resolve the tasks of national security in the spheres of science, technologies, and education it is necessary to ensure»:

- «the comprehensive development of scientific potential and the reinstatement of the complete scientific production cycle, ranging from basic scientific research to the introduction of the achievements of applied science into production in accordance with the priorities of the Russian Federation's socioeconomic, scientific, and scientific-technological development»;

- «the development of a national innovation system and encouragement and support for the development of the innovations market and scienceintensive output, including science-intensive output with high added value» ${ }^{1}$.

Foreign Policy Concept of the Russian Federation (approved by President of the Russian Federation Vladimir Putin on November 30, 2016) contains a special section: «Information Support for Foreign Policy Activities of the Russian Federation». Paragraph 47 of this section says: «Russia seeks to ensure that the world has an objective image of the country, develops its own effective ways to influence foreign audiences, promotes Russian and Russian-language media in the global information space, providing them with necessary government support, is proactive in international information cooperation, and takes necessary steps to counter threats to its information security. New information and communication technology is used to this end. Russia is intent on promoting a set of legal and ethical norms regarding the safe use of such technology. Russia asserts the right of every person to access unbiased information about global developments and various points of view» ${ }^{2}$.

${ }^{1}$ О Стратегии национальной безопасности Российской Федерации : указ Президента РФ от 31.12.2015 № 683 [Электронный ресурс] // Доступ из справ.-правовой системы «Гарант» (дата обращения: 15.10.2020).

${ }^{2}$ Президент подписал Указ «О Стратегии научно-технологического развития Российской Федерации» [Электронный ресурс]. URL: http://kremlin.ru/acts/news/53383 (дата обращения: 15.10.2020). 
Only recently, information security issues have become the subject of discussion at many summits and meetings at the international level at the level of heads of state. Information security is understood as the state of security of the information environment, ensuring its formation and development in the interests of certain structures. The information environment, being a backbone factor in people's life is a sphere of national security.

The modern world is «fundamentally dependent from the normal, uninterrupted functioning of the information infrastructure. The process of an avalanche-like widespread introduction of the latest information, telecommunication and cybernetic technologies is taking place. Along with the latter, the rapid spread of local and global networks creates a fundamentally new quality of cross-border information exchange. All of this directly affects politics, economy and security» [5, p. 115].

Let's turn to the concept of «information technology».

Russian legislation gives the following definition of information technology: «Information technologies are the processes, methods of searching, collecting, storing, processing, providing, distributing information and ways of implementing such processes and methods» ${ }^{1}$.

The choice of the specifics of information technology correlates with the humanities or with the technical one. «The interpretation of «information technology in politics» and «information technology used by policy subjects» imply the technical specifics of these technologies as a set of hardware and software for creating, processing, storing and transmitting data. The semantic meaning of the concepts «information technologies as political technologies» and «political information technologies» is based on the humanitarian component and is reduced to the methods of achieving political goals» [6, p. 83]. In this case, information technologies are considered as part of political technologies, which are understood as technologies of the struggle for political power and its retention, technologies for the distribution and application of political power [7, p. 135].

Information technologies in politics, as well as political technologies in general, are a rather complex concept and it primarily depends on the target audience or recipients and are used to develop political courses in order to modernize and optimize political processes.

The modern principles of e-government development are coming to the fore. The purpose of this ministry is to improve the existing and emerging

${ }^{1}$ Об информации, информационных технологиях и о защите информации : федер. закон от 27.07.2006 № 149-ФЗ [Электронный ресурс] // Доступ из справ.-правовой системы «КонсультантПлюс» (дата обращения: 15.10.2020). 
achievements of information technology for the fruitful administration of society and state institutions. The electronic state is included in all branches of government: judicial, executive, legislative [8, p. 304].

The phenomenon of the rapid development of information and communication technologies has also covered the segment of international relations. The term «digital diplomacy» was originally applied to US public policy pursued with the help of information and communication technologies. Digital diplomacy (electronic diplomacy) is the use of the capabilities of the Internet and information and communication technologies are to solve diplomatic and related tasks. Electronic diplomacy (ED) uses social networks, new media, blogs and other media platforms in the global network. State structures, primarily foreign policy, government bodies, as well as non-governmental organizations of foreign policy take part in electronic diplomacy [9, p. 70]. The main goals of electronic diplomacy are the promotion of foreign policy interests, information propaganda through Internet television, social networks, mobile communications, etc., aimed at the mass consciousness and at political elites. The field of application of e-diplomacy is very large, since the speed of information transfer is instantaneous and does not require much time, at the same time, it allows to affect more people, form a positive image of the country, contribute to the creation of a positive image of the country, distance learning. The big advantage of e-diplomacy is instant feedback from recipients [10, p. 48]. The data obtained make it possible to analyze them and assess the moods and expectations, fears and anxieties of citizens. The widespread introduction of communication channels for the rescue service and emergencies (air crashes, earthquakes, fires, etc.) are also invaluable. Selected political ideas are widely disseminated by means of electronic diplomacy. Individual citizens of certain nationalities living abroad have the opportunity to maintain their identity. So, e-diplomacy is an opportunity to expand its influence in the foreign policy arena, however, at the same time, there is a manipulative component that affects the addressees, forcing them to make pre-thought decisions.

Propaganda and agitation are varieties of political technologies. Propaganda is a certain vector of promotion of political ideas of the government and government structures with the aim of their subsequent consolidation of implementation and perception by members of society. Comparing to propaganda agitation and is a narrower concept and may be a propaganda tactic.

The ultimate goal of propaganda-type technologies is to establish dominance over the formation of points of view and to correlate their subsequent actions in accordance with the ideas suggested to members of society. In this 
case the basic strategies and tactics of propaganda and agitation are distortion, false information and manipulation.

To sum up the above mentioned, we come to the conclusion that the efficiency and usefulness of state administration and its functioning on the international arena entirely depends on new information technologies, which are a key factor in the very definition of the state's international and domestic security. And as a result, there are negative and positive aspects of the implemented achievements of information technologies. On the one hand, this is progress, on the other hand, it is vulnerability, a weak spot in the international security system. Responding to the challenges of our time it is necessary to bring to the fore on the agenda issues of information security, not only within a single country, but also in cooperation with other states.

\section{References}

1. Torkunov A.V. Po doroge $v$ budushchee -2 [On the road to the future - 2]. $2^{\text {nd }}$ ed. Moscow, Aspekt Press Publ., 2015. 552 p.

2. Afanas'eva E.N. New technologies in the field of artificial intelligence challenge the foundations of civil law. Vestnik Tomskogo gosudarstvennogo universiteta. Seriya: Pravo $=$ Bulletin of the Tomsk State University. Series: Law, 2020, no. 36, pp. 145-152. DOI: 10.17223/22253513/36/13. (In Russian).

3. Bovina I.B., Dvoryanchikov N.V. Living in a Digital Society: from the Point of View of One Social Psychological Perspective. Psikhologiia i pravo = Psychology and Law, 2020, vol. 10, no. 3, pp. 143-157. DOI:10.17759/ psylaw.2020100310. (In Russian).

4. Hazieva R.R., YUsupova R.R. Review on the Results of the III International Scientific Conference «Language, Law and Society in the Coordinates of Mass Media». Vestnik Instituta prava Bashkirskogo gosudarstvennogo universiteta $=$ Bulletin of the Institute of Law of the Bashkir State University, 2019, no. 2 (4), pp. 65-70. (In Russian).

5. Severcev N.A., Beckov A.V. Informacionnaya bezopasnost' i principy ee obespecheniya [Information security and principles of its provision]. Available at: https://cyberleninka.ru/article/n/informatsionnaya-bezopasnost-iprintsipy-ee-obespecheniya. (In Russian).

6. Smirnov A.I. Sovremennye informacionnye tekhnologii v mezhdunarodnyh otnosheniyah [Modern information technologies in international relations]. Moscow, MGIMO-Universitet Publ., 2017. 334 p. 
7. Degtyarev D.A. Prikladnoj kolichestvennyj analiz i modelirovanie mezhdunarodnyh otnoshenij [Applied Quantitative Analysis and Modeling of International Relations]. Moscow, RUDN Publ., 2016. 556 p.

8. Brumshtejn YU.M., Knyazeva O.M., Dyudikov I.A., Vas'kovskij E.YU. Nadezhnost' i kachestvo informacionnyh sistem: analiz sostava vliyayushchih faktorov s pozicij informacionnoj bezopasnosti [Reliability and quality of information systems: analysis of the composition of influencing factors from the standpoint of information security]. Available at: https:// cyberleninka.ru/article/n/nadezhnost-i-kachestvo-informatsionnyh-sistem-analiz-sostavavliyayuschih-faktorov-s-pozitsiy-informatsionnoy-bezopasnosti. (In Russian).

9. SHul'c V.L., Kul'ba V.V., SHelkov A.B., CHernov I.V. Scenarnyj analiz $v$ upravlenii geopoliticheskim informacionnym protivoborstvom [Scenario analysis in the management of geopolitical information confrontation]. Moscow, Nauka Publ., 2015. 542 p.

10. Nigmatullin, R.V., Minigulova I.R. Bor'ba s prestupnost'yu v kurse sovremennogo mezhdunarodnogo prava [The fight against crime in the course of modern international law]. Ufa, 2018. 85 p.

Received: 01.11.2020

\section{ИНФОРМАЦИОННЫЕ ТЕХНОЛОГИИ - ВЫЗОВ СОВРЕМЕННОСТИ}

\section{ХАЗИЕВА Рушана Рауфовна}

кандидат филологических наук, старший преподаватель кафедрь международного права и международных отношений Института права Башкирского государственного университета, г. Уфа, Россия. E-mail: rushanakhazieva@mail.ru

\section{ЮСУПОВА Розалия Римовна}

кандидат филологических наук, дочент кафедры международного права и международных отношений Института права Башкирского государственного университета, г. Уфа, Россия. E-mail: rozaliya-yusupova@yandex.ru

В статье уделяется внимание информационным технологиям и их классификации, рассматриваются преимущества и недостатки внедрения новейших информационных, телекоммуникационных и кибернетических 
технологий. Авторы считают, что необходимо объединить усилия всех стран для обеспечения информационной безопасности. Подчеркивается, что в современных условиях информационные системы одной страны являются частью глобальной системы, что, в свою очередь, приводит к уязвимости информационных систем и к возможности внешнего влияния на политику и экономику. Цель: показать положительные и негативные последствия достижений информационного обмена. Методы: общенаучные методы теоретического познания, а также общелогические методы и приемы исследования. Результаты: в современных условиях глобализации и интеграции различных мировых систем вопросы информационной безопасности должны оставаться приоритетными и рассматриваться в тесном сотрудничестве всех стран.

Ключевые слова: информационная революция; информационные технологии; информационная безопасность; государственная политика; информационный поток.

\section{Библиографический список}

1. Торкунов А.В. По дороге в будущее - 2. 2-е изд., доп. и перераб. М. : Аспект Пресс, 2015. 552 с.

2. Афанасьева Е.Н. Новые технологии в области искусственного интеллекта бросают вызов основам гражданского права // Вестник Томск. гос. ун-та. Сер.: Право. 2020. № 36. С. 145-152. DOI: 10.17223/22253513/36/13.

3. Бовина И.Б., Дворянчиков Н.В. Человек в цифровом обществе: объяснительный потенциал одной социально-психологической теории // Психология и право. 2020. Т. 10, № 3. С. 143-157. DOI:10.17759/ psylaw. 2020100310.

4. Хазиева Р.Р., Юсупова Р.Р. ІІІ Международная научная конференция «Язык, право и общество в координатах массмедиа» // Вестник Института права Башкирского государственного университета. 2019. № 2 (4). С. 65-70.

5. Северцев Н.А., Бецков А.В. Информационная безопасность и принципы ее обеспечения. URL: https://cyberleninka.ru/article/n/ informatsionnaya-bezopasnost-i-printsipy-ee-obespecheniya.

6. Смирнов А.И. Современные информационные технологии в международных отношениях : моногр. М. : МГИМО-Университет, 2017. 334 с.

7. Дегтярев Д.А. Прикладной количественный анализ и моделирование международных отношений. М. : РУДН, 2016. 556 с.

8. Надежность и качество информационных систем: анализ состава влияющих факторов с позиций информационной безопасности / Ю.М. Брум- 
штейн, O.M. Князева, И.А. Дюдиков, Е.Ю. Васьковский. URL: https://cyberleninka.ru/article/n/nadezhnost-i-kachestvo-informatsionnyh-sistem-analiz-sostava-vliyayuschih-faktorov-s-pozitsiy-informatsionnoy-bezopasnosti.

9. Сценарный анализ в управлении геополитическим информационным противоборством / В.Л. Шульц, В.В. Кульба, А.Б. Шелков, И.В. Чернов. М. : Наука, 2015. 542 с.

10. Нигматуллин, Р.В., Минигулова И.Р. Борьба с преступностью в курсе современного международного права : учеб. пособие. Уфа, 2018. 85 с.

Дата поступления: 01.11.2020 